\title{
Intervening Effect of Cash Holdings in the Relationship Between Financial Performance and Dividend Policy
}

\author{
Geoffrey Mbuva Kimunduu, PhD Candidate \\ Mirie Mwangi, PhD, Senior Lecturer \\ Prof. Erasmus Kaijage, PhD, Senior Lecturer \\ Duncan Elly Ochieng, PhD, Lecturer \\ University of Nairobi, School of Business \\ Department of Finance and Accounting, Nairobi, Kenya
}

Doi: 10.19044/esj.2017.v13n28p264 URL:http://dx.doi.org/10.19044/esj.2017.v13n28p264

\begin{abstract}
Many studies on relationship between financial performance and dividend policy have resulted to controversial outcome with few studies questioning the intervening effect of cash holdings. The purpose of this study was to evaluate the effect of cash holdings on the relationship between financial performance and dividend policy. The study applied positivism research philosophy and descriptive causal research design. The study was anchored on hypothetical view that the relationship between financial performance and dividend policy of firms listed at the Nairobi securities exchange is not intervened by cash holdings which was tested against a sample size of 31 firms listed at the Nairobi securities exchange selected using purposive sampling technique. The research findings were as follows: There was a significant direct association between operating cash flows and dividend policy which was intervened by cash holdings. In general it was concluded that the link between financial performance and dividend policy of firms listed at the Nairobi securities exchange was significant. The study outcome augment existing knowledge on financial performance and dividend policy for it is evident that firms with ability to generate income directly influence dividend payout ratio and therefore, top management should enhance financial performance and not dividend policy which is irrelevant. Cash holdings intervenes this relationship hence the level of cash balances maintained by the firm explain more on the reason why some firms pay more dividend on increase of profitability levels while others does not. Regulatory bodies such as Capital Market Authority and Centre for Corporate
\end{abstract}


Governance use these research findings to improve their financial viability assessment approach of firms listed at the Nairobi securities exchange.

Keywords: Financial performance, dividend, companies

\section{Introduction}

The debate on the causality implications of financial performance on firm dividend policy is diverse. Although dividend policy plays a key role in guiding the retention and distribution of firm earnings to shareholders, variations in financial performance does not assure the management a proportionate alteration of the dividend payout ratio due other factors that have intermediating effect (Alii, Khan \& Ramirez,1993). Gill and Shah (2012) defined cash holdings as demand for cash balances which can be easily used to facilitate investment activities on tangible assets or rewarding of the owners of the firm. Opler et al. (1999) also defined cash holdings as cash and marketable securities or cash equivalents. Cash holdings is the total amount of cash balances or cash equivalents which may take the form of cash balances in hand and at bank respectively and as government securities such as treasury bills which are of short term period.

Keynes (1936) argued that demand for cash balances is for three main motives; transactions, precautionary and agency/speculative intentions. Cash holdings for daily transaction purposes is meant to ensure that the firm is in a position to meet its daily operational requirements without external borrowing especially where cash is not readily available (Bates, Kahle \& Stulz, 2009). The intention of maintaining cash balances by firms for precautionary motive is to create a reserve to avoid loss of new profitable investment opportunities or being forced to access costly external finances (Majluf, 1984). The third reason for a firm to demand for cash balances is based on the agency/speculative-intention. Even when a firm is experiencing a low season of investment prospects, entrenched managers choose to keep cash other than to reward the owners of the firm for their investment through cash dividend payments (Dittmar \& Mahrt-Smith, 2007). This motive is triggered by the agency problem which prompts managers to retain more cash balances. Dittmar, Jan Marth-Smith and Henri Servaes (2003) justified this argument when they revealed that countries with agency problems have more cash reserves.

Dividend policy is the scheme and rule followed by the management when rewarding the owners of the firm for investing their financial resources in that venture (Nissim \& Ziv, 2001). Kehinde and Abiola (2001) defined dividend policy as a plan that guide management to distribute the returns of a firm to the common stock investors using diverse forms of dividends within a certain period of time. The scheme followed by a firm to distribute income, 
aims at achieving specific goals (Brigham \& Ehrhardt, 2012). According to Litner (1956), management continuously alternate the rate of dividend payments until it reaches an optimal dividend policy level in the long run. Hence dividend policy is summarized into three perspectives; the amount to pay, the frequency of dividend payments and the mode of paying dividends which is either in cash or non-cash form.

The amount to be paid by the firm to shareholders is further guided as either residual or stable dividend policies. The residual policy is employed by companies which rely on retained earnings to facilitate profitable projects which have been identified (Aduda \& Kimathi, 2011). This approach is applicable once all financing requirements of the firm have been met. Myers (1984) argued that firms distribute cash dividends to shareholders once all ventures which are viable have been fully financed using firm earnings. The implication of this action is that firms give first priority to the profitable investment opportunity and then reward shareholders with cash dividends in case there are some cash balances. Hence, the amount of cash to be distributed to the shareholders is determined by the cash balances after capital investment.

Contrary to residual approach, stable dividend policy entails payment of regular installments of a specific cash dividend quantity yearly regardless of company return fluctuations (Ap Gwilym, Morgan \& Thomas, 2000). Such guidelines include; fixed payout policy, fixed dividend per share policy and low-regular plus extra policy. The constant payout policy involves fluctuating periodical distribution of cash dividend to shareholders for the dividend plan is guided by a predetermined fixed proportion of the firm earnings. The shortcomings of this approach arise when earnings drop or worsen. In such a case the company experiences losses hence it will be forced to pay less or no dividend at all. This makes investors less assured of their cash dividend reward (Brigham \& Ehrhardt, 2012).The constant dividend per share is a dividend scheme whereby management sets a fixed amount of cash dividend per share to be paid to shareholders at any given period of time which translates to a periodical constant rate of change on dividend paid. This reduces uncertainty on future dividends since dividends become more predictable and as a result, the management makes an upward adjustment of cash dividend to be paid to shareholders if they are assured of permanent future firm earnings (AP Gwilym et al. 2000)

The low-regular plus extra policy involves payment of low regular dividends supplemented by an additional dividend whenever the company earnings are good or higher than normal in a given dividend period. The dividend strategy is convenient to the management for it matches low income seasons and high income periods with low to high rates of cash dividend in that order. This dividend arrangement creates confidence to 
shareholders for they are assured of at least some returns even during the loss making periods of the firm and also share improved returns when the firm has made some extra income in a particular period of time (Marsh, 2012).

Frequency of dividend payment is taken to imply the dividend timing which in the Kenyan context is commonly done semiannually (interim dividend) or at the end of the financial period (proposed dividend). Interim dividend is that part of total surplus declared and paid before the end of the financial period and the time intervals for making such payments is either quarterly or semiannually(IASB, 1998). Prior to payment of interim dividend, the accounting books of the firm are checked and confirmed by auditors. Final dividend, also known as proposed dividend is that part of firm earnings that is declared by the management at the end of the financial period to be paid at a later date based on audited financial results. In addition, the interim dividend paid in the course of the financial period, is assumed to be the final reward to the shareholders if the firm does not provide for final dividend (IASB, 1998). The current study used interim to total dividend ratio and dividend payout ratio to measure dividend policy (Maniagi et al. 2013).

Distribution of dividends to shareholders is also based on the manner of rewarding. The mode of distributing dividends to shareholders was classified by Copeland (1979) as cash and non-cash form. Although distribution of firm wealth to the shareholders is commonly done through cash dividend. In such a case, shareholders get a chance to invest the cash received in other opportunities of their choice, whereby the act adversely affect the firm net asset value. This is because payment of cash dividend entails an actual cash outflow which calls for taking precautions to avoid loss of liquidity position of the firm, hence a safety cash reserve is required. Fakru and Thoufiqulla (2013) defined stock dividend as the distribution of additional shares to the already existing shareholders free of charge. It is also referred to as of bonus or script issue. To measure bonus issue, Kibet et al. (2016) established a bonus ratio expressed as number of new shares (bonus) to existing shareholders per annum. Property is sometimes used as dividend whereby the shareholders are allocated physical assets instead of cash or additional free stocks.

The link between dividend policy and financial performance is governed by Jensen and Meckling (1976) agency theory which advocates that two parties, namely; the shareholder and the manager are in harmony in their interests. Modigliani and Miller (1961) argued that firm value and financial performance is associated with the ability of a firm to generate more earnings hence dividend policy is ineffective determinant financial performance of a firm (dividend irrelevance theory). Also, dividend policy is assumed to be a communication signal to pass valuable information to 
investors concerning future financial performance of the firm hence underpinned by the signaling theory (Al-Kuwari, 2009).

Leah (2008) defined financial performance as the measurement of the outcome of firm strategies, policies and operations. These results are reflected in the firm's return on assets and return on investments. Similarly, Adams and Mehran (2005) defined financial performance as the end result of primary utilization of firm assets to generate proceeds during ordinary business operations. Financial performance is used as a general measure of a firm overall financial level over a particular time duration and is used for comparison of general performance of different firms in the same industry. In general, financial performance is a gauge to express the general financial productivity of an organization over a span of financial period and aids in comparison of financial results of other firms in the same sector. There is no one universally accepted proxy for measuring the financial performance of a firm. However, the level of financial performance explains the extent to which a firm has succeeded (Waweru, 2008). Financial performance of a firm based on both accounting and market perspectives (Waggoner, Neely \& Kennerley, 1999).

The various accounting based proxies used to measure financial performance are; return on equity (ROE), earnings per share (EPS), return on assets (ROA) and operating cash flows (OCF) (Millet-Reyes \& Zhao, 2010). The accounting based indicators provide a short term financial performance implications to the management and also their values are determined from historical data and therefore they cannot be fully relied upon to make future firm decisions (Klapper \& Love, 2002). These measures are also anchored on accounting based professional rules, regulations and standards. However, operating cash flows is one of the accounting based proxies which is least adversely influenced by the accounting practices (Ahmed \& Javid, 2009). Current study used ROE and operating cash flows as accounting based approaches to measure financial performance of the firms under study. Return on equity is the profit after tax to total equity quotient (Al-Malkawi, 2007). Operating cash flows is expressed as the coefficient of the sum of profit after taxation (PAT) and noncash items and total assets net of cash and cash equivalents (Millet-Reyes \& Zhao, 2010).

The market based indicators used in measuring financial performance of a firm are varied. Some of those proxies are; Tobin's Q, market to book value (MTB), dividend yield (DY) and price earnings (PE) which are futuristic and long term in nature. These market-based proxies represent the expectations of the shareholders on the firm's future performance (Omran \& Pointon, 2004). The current study used MTB and price earnings to gauge financial performance. The market to book value is a coefficient representing the ratio of market to book value of common stock (Fairchild \& Li, 2005) 
whereas, price earnings is a coefficient of market price of common stock and earnings per share of a firm (Ehikioya, 2009).

\section{Literature Review}

There are various factors that determine dividend policy. Financial performance and cash holdings are some of the factors that predict the type of dividend policy a firm implements although past studies interrogated them using bivariate models to show the cause effect association thereof. For instance, Litner (1956) argued that as firm profitability change, dividend payout ratio change simultaneously. Hence, management would pay either more or less cash dividends to the shareholders depending on the change which occur. Contrary, dividend policy is used by the firms as a signal to communicate future prospects of the organization. From a different perspective, when firm management predict better returns in the future, dividend payout ratio is increased to attract shareholders. Whereas, reliance on a less attractive dividend policy imply a future earnings decline (Arnott \& Asness, 2003). Cash holdings and dividend policy also portray an association. Past literature shows that its cause-effect implication on either financial performance or dividend policy is not universally agreed upon by researchers.

Ogundipe, Ogundipe and Ajao (2012) in their study hypothesized that the relationship between cash holdings and firm characteristics was statistically significant. The objective of the study was achieved by selecting 54 firms registered at the Nigerian stock bourse as the study sample. The period covered by the study was 15 years from 1995 to 2010. Correlation research design was used to analyze the data and the research findings exposed that corporate cash holdings was significantly affected by cash flow, net working capital, leverage, profitability and investment in capital expenditure. This outcome implied that those aforementioned predictor variables determined the level of cash balances for firms listed at the Nigerian securities exchange. Similarly the study by Afza and Adnan (2007) incorporated several factors which were postulated as factors that influence cash holdings. They entailed firm size, investment growth opportunities, cash flow, net working capital, leverage, cash flow volatility and dividend payouts. Pakistani non-financial firms were chosen for the study and their data for a period of 8 years from 1998 to 2005 was collected for analysis. The research findings showed that market-to-book ratio, net working capital, leverage and dividend payouts had converse effect on cash holdings. There was a direct impact of firm size and operating cash flows on cash holdings. This implies that as the value of the determinants increased, cash balances of the firm increased. 
Ferreira and Vilela (2004) based their study on the causes of variations in firm cash holdings value over time. The study identified investment opportunity set, cash flows, asset liquidity, leverage and firm size as independent variables and cash holdings as response variable. The sample used to collect data was made up of four hundred organizations (400) drawn from 12 Economic and Monetary Union (EMU) states. Data used was accessed from financial records of those firms for thirteen years (19872000). Results depicted that proportionate change in investment opportunity set and cash flows led to a proportionate change in cash holdings. Whereas, cash holdings was inversely influenced by asset liquidity, leverage and firm size.

Contrary, Abushammala and Sulaiman (2014) examined whether cash holdings influenced firm performance using profitability aspect. The study ignored the intermediating effect of cash holdings. A sample of 65 firms listed at the Amman stock exchange and which were non-financial based were selected for the study for a timeframe of twelve years from 2000 to 2011. Simple regression models were used for data analysis. It was established that there was statistically positive significant influence of cash holdings on profitability of the firms. It was shown that progressive financial performance of a firm is connected to maintenance of cash balances by the management. This positive relationship was supported by Jordanian firm management who believed that lack of effective liquidity management causes cash shortages and this would lead to difficulties in paying obligations as and when they fall due, which negatively affect firm profitability. Hofmann (2006) in his study endeavored to determine causes of cash holding variations amongst non- financial firms of New Zealand. He anticipated firm growth opportunities, cash flow volatility, leverage, dividend payments and the availability of liquid asset substitute as predictors of cash holdings alterations. The study outcome revealed that there was a positive correlation between growth opportunities, leverage and the variability of cash flows and cash holdings. Whereas, the relationship between dividend payments and liquid asset substitutes and cash holdings was low.

Nguyen (2005) carried a similar study to that of Hofmann (2006) whereby he sought to investigate how various predictors impacted on cash holdings. He used similar variables to those of Hofmann (2006) such as firm growth rate and dividend policy in addition to firm profitability and risk level. A sample size of 9,168 Tokyo stock exchange member firms was selected for the study between 1992 and 2003. The outcome showed that to a greater extent, profitability, firm growth rate prospects, dividend policy and risk level contributed to an upward transformation in cash holdings value. Whereas an inverse relationship between cash holdings and industry risk, 
firm size and debt ratio prevailed. In both studies, dividend policy was assumed to influence cash holdings. In addition, the two studies used similar independent variables such as dividend payouts to predict cash holdings although dissimilar results were realized. The study by Banafa, Muturi and Ngugi (2015) aimed at interrogating the causality effect of cash holdings on financial performance of firms. The study used a population of 42 nonfinancial firms in Kenya and adopted causal research design. Data analysis output was presented using descriptive statistics and inferential analysis such as t-test. A simple regression model was used. The research findings revealed that cash holdings was associated to change in financial performance using ROA as the proxy. Banafa et al. (2015) study considered cash holdings as an independent variable while Nguyen, (2005) and Hofmann (2006) classified cash holdings as independent variable. Hence controversial results were obtained which does not clearly identify the role of cash holdings in the relationship between financial performance and dividend policy.

\section{Research Problem}

The dilemma of whether changes in financial performance lead to proportionate change of dividend payout ratio of firms has not been resolved for a long period of time (Dada, Malomo \& Ojediran, 2015). Jensen and Meckling (1976) argued that a firm that is highly geared and at the same time generating more profits, follows a low dividend payout ratio for it retains a big proportion of its earnings to meet debt obligations as and when they fall due. Such that as financial performance increase, dividend payout ratio decline, a change that represent an inverse connection. In cases where the firm is located in countries with strong legal framework that protects investors' rights, management is required by law to distribute cash dividends. In this case, financial performance and dividend payout have a direct linkage (La Porta et al. 2000).

For firms with increased returns, Litner (1956) argued that it is more sensible to reflect such financial outcome by distributing more cash dividends to the shareholders. Therefore, past studies on financial performance and dividend policy had dissimilar research findings. Also such results were dominated by firms listed at securities exchange located in developed countries such as United States of America (USA), Britain and Japan while firms in emerging economies were ignored (Maniagi et al. 2013). Globally, empirical literature showed diversified findings regarding relationship between financial performance and dividend policy. Maladjian and El Khoury (2014) carried out a study in Lebanon and found that dividend payout policy of firms listed at the Beirut stock exchange was determined by previous financial period dividends declared, firm size and 
risk level. Firm growth rate and profitability portrayed an inverse relationship. In Pakistan, it was established that, firms in the banking sector were prompted to distribute dividends proportionately to profitability levels (Hashim, Shahid, Sajid \& Umair, 2013).

In Kenya, a study carried out by Odawo (2015), revealed that dividend policy of firms listed at the Nairobi securities exchange depend on the firm liquidity, debt equity ratio, profitability and firm size. Bulla (2013) sought to investigate the causes of variations in dividend policy of public firms listed at the Nairobi securities exchange. The factors under consideration in this study were; current firm returns, dividend yield and the size of the firm. It was established that the three factors influenced dividend payout ratio in a significant manner.

Past studies failed to demonstrate the intermediating role of cash holdings in the relationship between financial performance and dividend policy. This obliges a study of this nature especially for firms listed at the Nairobi securities exchange. The study hypothesized that the relationship between financial performance and dividend policy of firms listed at the Nairobi securities exchange is not intervened by cash holdings.

\section{Data and Methodology}

The study relied on positivism philosophy and adopted descriptive causal research design for it involved analyzing of the relationship between financial performance and dividend policy to determine cause-effect implications. The study population was 46 firms listed at the Nairobi securities exchange out of which 31 firms were selected as the study sample for analysis using purposive sampling technique. Data was collected from financial statements of the relevant firms from both Nairobi securities exchange and Capital Market Authority websites and library facilities. The longitudinal panel data obtained covered a period of eleven years, from January 2005 up to December 2015. Using STATA software 13, inferential analysis was performed on variables using stepwise regression models. The financial performance was the independent variable and was operationalized as operating cash flows (OCF). Dividend policy was the dependent variable in this study and was measured using two proxies, namely; interim dividend to total dividend ratio and dividend payout ratio expressed as the total dividend to annual earnings attributable to shareholders. Whilst, cash holdings was measured by Gill and Shah (2012) as the cash and cash equivalents value expressed in terms of book value of total assets net of cash and equivalents.

The intermediating effect of cash holdings was tested by adopting a procedure of three steps as depicted below:- 
Step one: Intermediation between Financial Performance (FP) and Dividend Policy (DP) (cash holdings is constant)

$\mathrm{DP}_{\text {it }}=\beta_{0}+\beta_{1} \mathrm{OCF}_{\mathrm{it}}+\varepsilon_{\mathrm{i}}$

Where:

$\mathrm{DP}_{\mathrm{it}}$ is Dividend Policy

$\mathrm{OCF}_{\text {it }}$ is operating cash flows of firm $\mathrm{i}$ in time $\mathrm{t}$

$\beta_{0}$ is regression constant

$\beta_{1}$ is regression coefficient of $\mathrm{OCF}$

$\varepsilon_{i t}$ is the random error term.

Step two: Intermediation between OCF and Cash Holdings $(\mathrm{CH})$. (Dividend Policy is constant);

$\mathrm{CH}_{\mathrm{it}}=\beta_{0}+\beta_{2} \mathrm{OCF}_{\mathrm{it}}+\varepsilon_{\mathrm{it}}$

Where:

$\mathrm{OCF}_{\text {it }}$ is operating cash flows of firm $\mathrm{i}$ in time $\mathrm{t}$

$\mathrm{CH}_{\text {it }}$ is Cash Holdings

$\beta_{0}$ is regression constant

$\beta_{2}$ is regression coefficient of $\mathrm{CH}$

$\varepsilon_{i t}$ is the random error term.

Step three: Intermediation amongst DP, CH and FP as follows;

$\mathrm{DP}_{\mathrm{it}}=\beta_{0}+\beta_{4} \mathrm{OCF}_{\mathrm{it}}+\beta_{5} \mathrm{CH}_{\mathrm{it}}+\varepsilon_{\mathrm{i}}$

Where;

$\mathrm{DP}_{\text {it }}$ is composite value of dividend policy

$\beta_{0}$ is $y$ intercept or regression constant

$\beta_{4}$ and $\beta_{5}$ are Regression coefficients

$\mathrm{OCF}_{\text {it }}$ is operating cash flows of firm $\mathrm{i}$ in time $\mathrm{t}$

$\mathrm{CH}_{\mathrm{it}}$ is cash holdings of firm $\mathrm{j}$ in time $\mathrm{t}$

$\varepsilon_{i t}$ is the random error term.

Mediation (intervention) occurs if predictor variable (OCF) significantly predicts both response variable (dividend policy) and intervening variable (cash holdings) but no longer significant in the presence of intervening variable (cash holdings) (Baron \& Kenny, 1986).

Data on OCF and dividend policy was analyzed using descriptive statistics of mean, standard deviation, skewness (SK) and kurtosis (KU) while stepwise regression analysis was employed in establishing the relationship between the variables.

\section{Results and Discussion}

The data for the variables of study concern were assembled from 31 firms listed at the Nairobi securities exchange and a summary of the descriptive statistics outcome was represented in Table 1,2 and 3 which revealed that indicators of dividend policy, operating cash flows. The linear regression results are shown in Table 3. 
Table 1: Summary of Descriptive Statistics for Dividend Policy

\begin{tabular}{cccccc}
\hline Variable & $\mathrm{N}$ & Mean & SD & SK & KU \\
\hline DP & 341 & 0.20 & 0.26 & 0.49 & 8.74 \\
\hline
\end{tabular}

$S D$ is standard deviation,

SK is skewness, $K U$ is kurtosis

Source: Research Data

Table 2: Summary of Descriptive Statistics for Operating Cash Flows

\begin{tabular}{cccccc}
\hline Variable & $\mathrm{N}$ & Mean & SD & SK & KU \\
\hline OCF & 341 & 0.09 & 0.15 & 8.57 & 123.43 \\
\hline
\end{tabular}

$S D$ is standard deviation, $S K$ is skewness, $K U$ is kurtosis

Source: Research Data

Table 3: Regression Results of Mediating Effect of Cash Holdings on Operating Cash Flows and Dividend Policy

\begin{tabular}{|c|c|c|c|}
\hline Variable & $\begin{array}{c}\text { Model 1 } \\
\text { (DP \& OCF) }\end{array}$ & $\begin{array}{c}\text { Model 2 } \\
\text { (CH \& OCF) }\end{array}$ & $\begin{array}{c}\text { Model 3 } \\
\text { (DP, OCF \& CH) }\end{array}$ \\
\hline Constant & $.158(0.000)$ & $.033(0.001)$ & $.142(0.000)$ \\
\hline OCF & $.481(0.000)$ & $-338(0.000)$ \\
\hline CH & - & $0.278(0.000)$ & $.514(0.000)$ \\
\hline & & & 0.1559 \\
\hline Adj. $\mathrm{R}^{2}$ & 0.0723 & 0.0688 & $32.39(0.000)$ \\
\hline F & $27.48(0.000)$ & $26.11(0.000)$ & \\
\hline
\end{tabular}

$\mathrm{p}$ - Values in parenthesis
a. Dependent variable: Dividend Policy
b. Dependent variable: Cash Holdings
c. Dependent variable: Dividend Policy

In step one of the mediation models (model 1) regression analysis was performed to assess the connection between dividend policy (response variable) and operating cash flows (predictor variable) while ignoring the mediator (cash holdings). According to Table 3 above, the model was statistically significant ( $\mathrm{p}$-value<.05). The multiple regression models produced adjusted $\mathrm{R}^{2}$ of .0723 , with computed value of $\mathrm{F}=27.48$ and $(\mathrm{p}<$ $.05)$. This implies that OCF explained $7.23 \%$ of the variations in dividend policy. The test of the slope showed that the regression coefficient $(\beta)$ value of OCF was 0.481 with a significance level (p-value) of 0.000. This indicated that OCF is a significant predictor variable $(\mathrm{p}<.05)$ of dividend policy and therefore a relationship exist between the two variables. The first mediation condition which states that the response variable should be significantly linked to the response variable in the absence of the mediating variable was thus satisfied.

In the second step of the mediation process, regression analysis was performed to assess interlink between cash holdings (intervening variable) and OCF (predictor variable) ignoring the response variable (dividend 
policy). Model 2 was found to be statistically significant (p-value <.05) as shown in Table 3 above. The multiple regression model produced adjusted $\mathrm{R}^{2}=.0688$ and $\mathrm{F}=26.11$ with a $(\mathrm{p}<.05)$. In this case OCF explained $6.88 \%$ of variations in cash holdings $(\mathrm{CH})$. Test of the slope showed that the regression coefficient $(\beta)$ value of OCF was 0.278 which had a significant value of ( $\mathrm{p}-0.000$. Therefore it was established that OCF was a significant predictor variable $(\mathrm{p}>.05)$ and therefore a significant relationship existed between OCF and cash holdings. According to Table 3, it was indicated that the second condition which states that the predictor variable should be significantly related to the mediating variable was satisfied.

The third step of the mediation analysis was performed to assess the relationship between dividend policy (dependent variable), cash holdings (intervening variable) and OCF (independent variable). As shown in Table 3 above, the model (model 3) was statistically significant (p-value<.05). The multiple regression model produced adjusted $\mathrm{R}^{2}$ of .1559 . The value computed of $\mathrm{F}=32.39$ and $(\mathrm{p}<.05)$. Hence OCF and cash holdings explained $15.59 \%$ of the variations in dividend policy. Test of the slope showed that the regression coefficient $(\beta)$ value of OCF was .338 with a significance level ( $p$ value) of 0.000 while the regression coefficient $(\beta)$ value for cash holdings was 0.514 with a significance level of .000 . The results as per (model 3 ) in Table 3 above depicted that the effect of the independent variable (OCF) on the dependent variable (DP) was significant $(\mathrm{p}<.05)$ in the presence of the mediating variable $(\mathrm{CH})$ although operating cash flows (OCF) coefficient dropped from .481 to .338 in the presence of cash holdings. Hence, failed to accept the null hypothesis $2\left(\mathrm{H}_{02}\right)$; that the relationship between financial performance (OCF) and dividend policy of firms listed at the Nairobi securities exchange is not intervened by cash holdings. This implies that cash holdings intervene the relationship between financial performance and dividend policy.

The analytical model is thus specified as;

$\mathrm{DP}_{\mathrm{it}}=.142+.338 \mathrm{OCF}+.514 \mathrm{CH}$

\section{Conclusion}

The objective of the study was to evaluate the effect of cash holdings on the relationship between financial performance and dividend policy of firms listed at the Nairobi securities exchange. The Baron and Kenny (1986) approach was employed in order to carry out that test. The mediation test satisfied the first two conditions that should be met for a mediation relationship to be in existence although the third condition was partially fulfilled. That is, the research findings established that cash holdings had a statistically significant $(\mathrm{p}=0.000)$ intervening effect on the relationship 
between financial performance (OCF) and dividend policy of firms listed at the Nairobi securities exchange. The study was affirmed by Banafa, Muturi and Ngugi (2015) who established that cash holdings had a positive effect on financial performance of the firm (ROA). This implies that cash holdings have an intervening effect to financial performance of a firm.

That is, the relationship between financial performance and dividend policy is not direct but rather intervened by cash holdings. This explains why many researchers in corporate finance experience a puzzle (Black, 1976) when interrogating the relationship between financial performance and dividend policy which in the past studies have resulted to contradictory outcomes with some authors concluding the relationship between the variables to be positive, negative or lacking an association.

\section{References:}

1. A.Abushammala, S. N. M. \& Sulaiman, J. (2014). Cash holdings and corporate profitability: Some evidences from Jordan, International Journal of Innovation and Applied Studies, 3(8), 898-907.

2. Adams, R. B. \& Mehran, H. (2005). Corporate performance, board structure and its determinants in the banking industry, in EFA, Moscow meetings.

3. Aduda, J. O. \& Kimathi, H. (2011). The Applicability of the constant dividend model for companies listed at the Nairobi stock exchange, Journal of Financial Studies \& Research, pp. 1-38.

4. Afza, T. \& Adnan, S. M. (2007). Determinants of corporate cash holdings: A case study of Pakistan. Proceedings of Singapore Economic Review Conference (SERC) 2007, August 01-04, organized by Singapore Economics Review and the University of Manchester (Brooks world poverty institute), Singapore 164-165.

5. Ahmed, H. \& Javid, A. Y. (2009). Dynamics and determinants of dividend policy in Pakistan: evidence from Karachi stock exchange non- financial listed firms. Journal of Finance and Economics, 25(1), 148-171.

6. Alii, K. L., Khan, A. Q. \& Ramirez, G. G. (1993). Determinants of corporate dividend policy: A factorial analysis, Financial Review, 4(28), 523-547.

7. Al-Kuwari, D. (2009). Determinants of the dividend payout ratio of companies listed on emerging stock exchanges: The case of the Gulf Cooperation Council (GCC) countries. Global Economy \& Finance Journal, 2(2), 38-63.

8. Al-Malkawi, H. (2007). Determinants of corporate dividend policy in Jordan: An application of the Tobit Model, Journal of Economics and Administrative Sciences, 23(2), 44-70. 
9. Ap Gwilym, O., Morgan, G. \& Thomas, S. (2000). Dividend stability, dividend yield and stock returns: UK evidence. Journal of Business Finance and Accounting, 27(3), 261-281.

10. Arnott, R. \& Asness, C. (2003). Surprise! Higher dividends = higher earnings growth. Financial Analysts Journal, 59(1), 70-87.

11. Banafa, A. S, Muturi, W. \& Ngugi, K. (2015). The liquidity factor in the financial performance of non-listed financial firms in Kenya. European Journal of Business and Management 4(7), 1- 24.

12. Baron, R. M. \& Kenny, D. A. (1986). The moderator-mediator variable distinction in Social Psychological Research: Conceptual, strategic, and statistical considerations. Journal of Personality and Social Psychology, 51(6), 1173-1182.

13. Bates, T. W., Kahle, K. M. \& Stulz, R. (2009). Why do U.S.A. firms hold so much more cash than they used to? Journal of Finance, 64(5), 1985-2021.

14. Black, F. (1976). The dividend puzzle. Journal of Portfolio Management, 2(2), 5-8.

15. Brigham, E. F. \& Ehrhardt, M. C. (2012). Financial management: Theory and practice, 13 th edition, South-Western publication.

16. Bulla, D. M. (2013). An empirical analysis of selected factors affecting dividend policy of listed firms at the Nairobi securities exchange. African Journal of Accounting, Economics, Finance and Banking Research, 9(9), 14-23.

17. Copeland, T. E (1979). Liquidity changes following share splits. Journal of Finance, 1(34), 115-141.

18. Dada, F. B., Malomo, E. \& Ojediran, S. (2015). Critical evaluation of the determinants of dividend policy of banking sector in Nigeria, International Journal of Economics Commerce and Management, 3(2), 1-11.

19. Dittmar, A. \& Mahrt-Smith, J. (2007). Corporate governance and the value of cash holdings. Journal of Financial Economics, 83(3), 599-634.

20. Dittmar, A. Mahrt-smith, J. \& Servaes, H. (2003). International corporate governance and corporate cash holdings. Journal of Financial and Quantitative Analysis, 38(1), 111-133.

21. Ehikioya, B. (2009). Corporate governance structure and firm performance in developing economies: Evidence from Nigeria. Q Emerald Group Publishing Limited, 9(3), 231-243.

22. Fakru, K.Y. \& Thoufiqulla, P. (2013). An analysis of bonus share issued and its impact on share price with reference to listed stocks in India. Acme Intellects International Journal of Research in Management, 4(4), 1-13. 
23. Ferreira, M. A. \& Vilela, A. S. (2004). Why do firms hold cash? Evidence from EMU countries. European Financial Management, 10(2), 295-319.

24. Gill, A. \& Shah, C. (2012). Determinants of corporate cash holdings: Evidence from Canada. International Journal of Economics and Finance, 4(1), 70-79.

25. Hashim, Z., Shahid, R., Sajid, I. \& Umair, A. (2013). Determinants of dividend policy: A case of banking sector in Pakistan, Middle East Journal of Scientific Research, 18(3), 410-424.

26. Hofmann, C. (2006). Why New Zealand companies hold cash: An empirical analysis unpublished thesis (PhD thesis).

27. IASB. (1998). International Accounting Standard 34, International Accounting Standards Board, IFRS Foundation.

28. Jensen, M. C. \& Meckling, W. H. (1976). Theory of the firm: Managerial behavior, agency costs, and ownership structure, Journal of Financial Economics, 4(3), 305-360.

29. Kehinde, J. S. \& Abiola, J. O. (2001). Foundation of Financial Management, Life Spring House publisher Agege, Lagos (Nigeria).

30. Keynes, J. M. (1936). The General theory of employment, interest and money. London: Mac-Millan.

31. Kibet, W. T., Jagongo, A. O. \& Ndede, F.W. S. (2016). Effects of dividend policy on share price of firms listed at the Nairobi Securities Exchange, Kenya. Research Journal of Finance and Accounting, 8(7), 220-230.

32. Klapper, L. \& Love. I. (2002). Corporate governance, investor protection, and performance in emerging markets. Washington, DC. United States: World Bank. Mimeographed document.

33. La Porta, R. F., Lopez-De-Silanes, A. S. \& Vishny, R. (2000). Agengy problems and dividend D'Souza, J. 1999. Agency cost, market risk, policies around the world, Journal of Finance, 55(1), 134.

34. Leah, M. (2008). Interest rate forecasts, financial markets group, London School of Economics and Political Science, 42(3), 201-231.

35. Lintner, J. (1956). Distribution of incomes of corporations among dividends, retained earnings and taxes, American Economic Review, 46(2), 97- 113 .

36. Maladjian, C. \& El Khoury, R. (2014). Determinants of the dividend policy: An empirical study on the Lebanese listed banks. International Journal of Economics \& Finance, 4(6), 240252.

37. Maniagi, G. M., Denco, M. J., Ondiek, B. A., Okaka, D. \& Musiega, D. (2013). Corporate governance, dividend policy and performance. 
special reference to banks listed on Nairobi security exchange Kenya. International Journal of Innovative Research \& Development, 5(2), 56-69.

38. Marsh, C. (2012). Financial Management for non-financial managers, Kogan Page.

39. Millet-Reyes, B. \& Zhao, R. (2010). A comparison between one-tier and two-tier board structures in France. Journal of International Financial Management and Accounting, 21(3), 279-310.

40. Modigliani, F. \& Miller, M. (1961). Dividend policy, growth and the valuation of shares. The Journal of Business, 34(4), 411-428.

41. Myers, S. C. (1984). The capital structure puzzle. The Journal of Finance. 39(3), 574-592.

42. Nguyen, P. (2005). How sensitive are Japanese firms to earnings risk? Evidence from cashholdings.1-41.

43. Nissim, D. \& Ziv, A. (2001). Dividend changes and future profitability. The Journal of Finance, 56(6), 2111-2133.

44. Odawo, C. (2015). Determinants of dividend payout policy in public ltd banks in Kenya: A case study of CFC Stanbic bank. Strategic Journal of Business \& Change Management, 2(2), 16-28.

45. Ogundipe, L. O., Ogundipe1, S. E. \& Ajao, S. K. (2012). Cash holding and firm characteristics: Evidence from Nigerian emerging market. Journal of Business, Economics \& Finance, 2(1), 45-58.

46. Omran, M. \& Pointon, J. (2004). Dividend policy, trading characteristics and share prices: Empirical evidence from Egyptian firms, International Journal of Theoretical and Applied Finance, 7(2), 121-33.

47. Opler, T., Pinkowitz, L., Stulz, R. \& Williamson, R. (1999). The determinants and implications of corporate cash holdings. Journal of Financial Economics, 52(1), 3-46.

48. Waggoner, D., Neely, A. \& Kennerley, M. (1999). The forces that shape organizational performance measurement systems. An interdisciplinary review. International Journal of Production Economics, 60(61), 53-60.

49. Waweru, M. A. S. (2008). Competitive strategy implementation and its effect on performance in large private sector firms in Kenya, Unpublished $\mathrm{PhD}$ Thesis, University of Nairobi. 


\section{Appendices}

Appendix 1: Trend Analysis for Operating Cash Flows

OCF

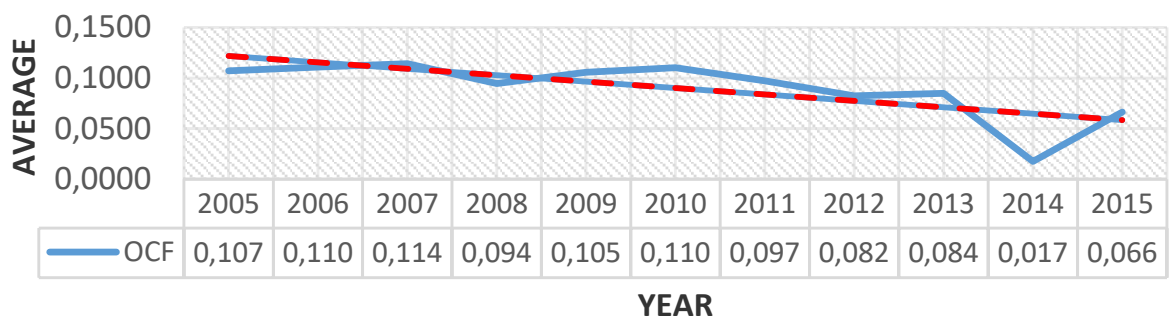

\section{Appendix 2: Trend Analysis for Cash Holdings}

\section{$\mathrm{CH}$}

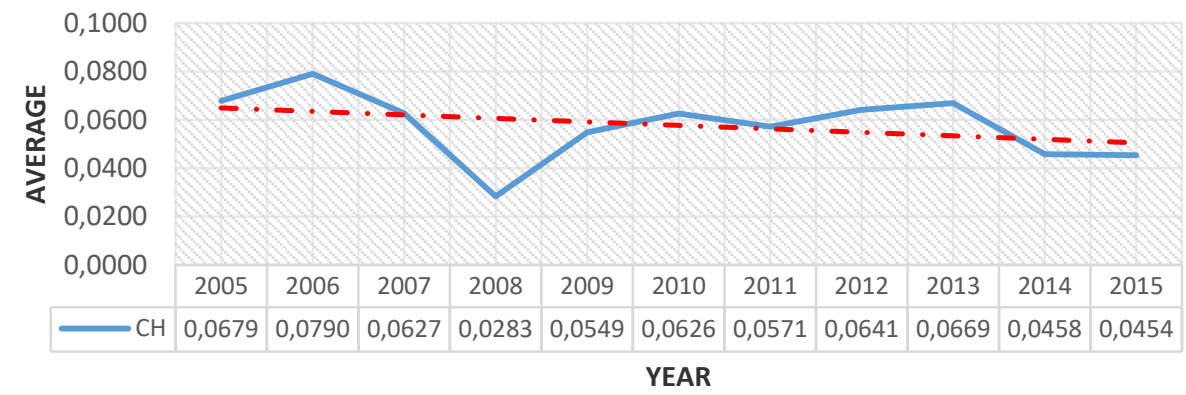

\section{Appendix 3: Trend Analysis for Dividend Policy}

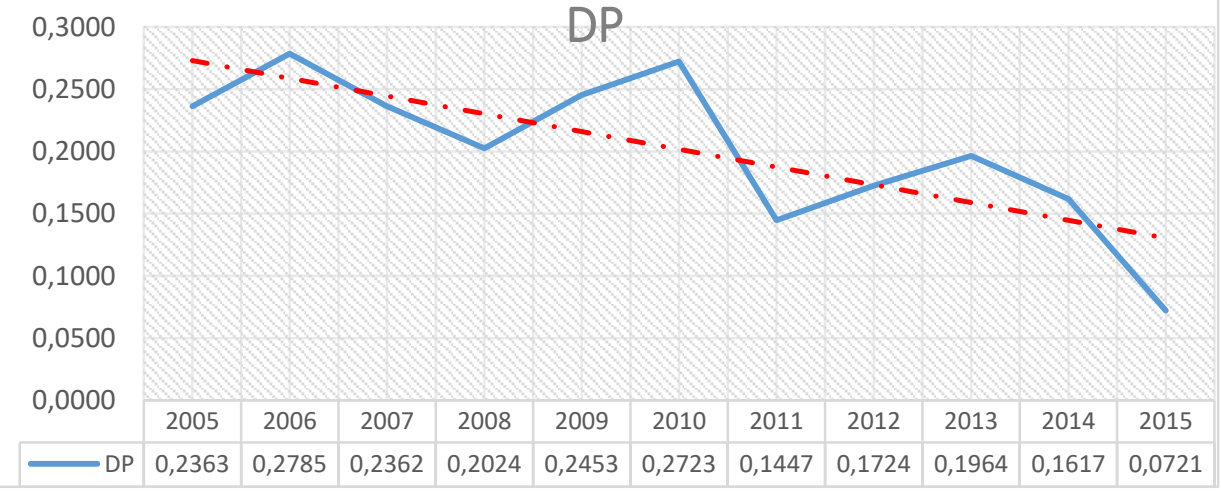


Appendix 4: Normality Test Summary for Individual Study Variables

Operating Cash Flow

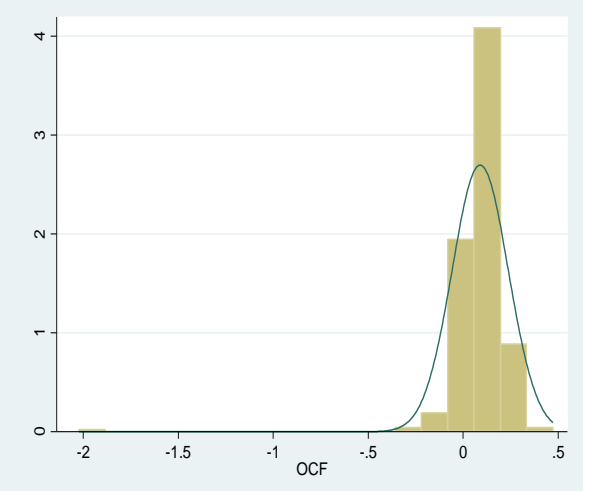

Dividend Policy

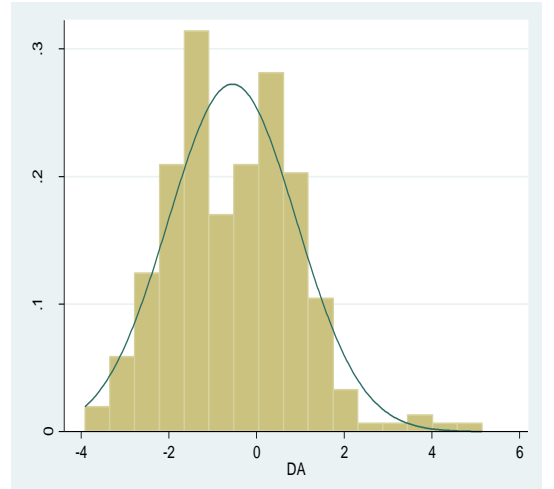

Cash Holdings

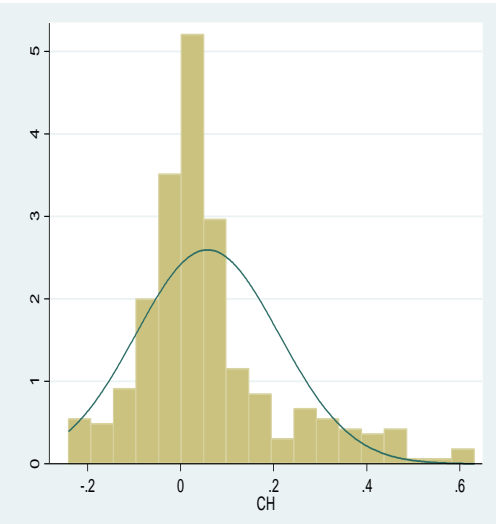

